\title{
Field Investigation on Transmission Loss \& Water Use Efficiency in Sub Minors of Sardar Sarovar Command of Middle Gujarat India
}

\author{
Murari Lal Gaur ${ }^{1}$, V. K. Sood ${ }^{2}$, A. I. Saikh ${ }^{3}$ \\ Professor, Dept. of Meteorology \& Agril. Engg., B A College of Agriculture, Anand Agril. University, Anand, India ${ }^{1}$ \\ Assoc Prof., Dept. of Meteorology \& Agril. Engg., B A College of Agriculture, Anand Agril. University, Anand, India ${ }^{2}$ \\ Credit Manager, India Shelter Finance Corporation Ltd, Vadodara Gujarat India ${ }^{3}$
}

\begin{abstract}
Appropriate accounting for irrigation water is gaining a high attention in prevailing irrigated agriculture. It remains inevitable to judge \& establish region specific paradox of irrigation efficiency (both for traditional \& micro irrigation systems). Dynamic behaviour of canal-based irrigation water inflows \& outflows is evaluated at micro scales in pre-identified micro commands of three sub-minors under prestigious Sardar Sarovar Narmada Nigam Limited (SSNNL) irrigation project in Gujarat India. Magnitudes as well as ranges of various elements \& indicators of physical canal systems, cropping systems, and irrigation water operations are critically evaluated to derive ground based factual values of Water Use Efficiencies (WUE), crop productivities, and canal water losses. WUE values were worked out to be as $10.02 \mathrm{~kg} / \mathrm{ha} / \mathrm{mm}$ for maize crop, $8.15 \mathrm{~kg} / \mathrm{ha} / \mathrm{mm}$ for caster crop and $4.37 \mathrm{~kg} / \mathrm{ha} / \mathrm{mm}$ for cotton crop. The overall trends, patterns of variations, interconnectivities, and location specific actual values of several end deliverables (dynamics of irrigation water fronts during their advancement \& recession phases, soil water losses, canal conveyance losses, WUE, crop productivities, irrigation operating indicators etc) are reported herein. Relative comparison of overall system performance and operative indicators in micro commands for study sub-minors (namely Sankheda, Umara-Jabusar and Kadadara-Vehlal during their $1^{\text {st }}$ phase of execution i.e. 2010-11 Rabi season) are presented, along with certain food for thought on futuristic interventions on theme of this writeup.
\end{abstract}

Keywords: Sub-minors, Water Use Efficiency, Conveyance Losses, Micro-Irrigation, Infiltration Rates

\section{INTRODUCTION}

Irrigated agriculture makes an important contribution to food production \& rural development in many deprived countries of the World. Today's agriculture accounts for the majority of global water withdrawals, and is often responsible for $80 \%$ or more of total withdrawals in developing countries. As populations continue to rise, irrigation will be further called upon to provide an increasing share of total food production to meet the growing demand. In next 3 or 4 decades, the world food production will certainly need to be more than double to meet the demands of increased population. About $90 \%$ of this increased food production will have to come from existing lands \& not less than $70 \%$ of this increased food production will have to come from irrigated land. Under prevailing climate change scenario, the uncertainties and insufficiencies of rainfall are well recognized in most parts of the tropical regions like India. Without precious irrigation, farming is becoming just limited \& less productive. Efficient means and methods of irrigation are critical needs of hour, as they have vast potential to increase crop yield, protection from droughts/famine, cultivation of superior high-income crops and many other socio-economic benefits for the society and environment. Irrigation water offers enormous benefits like improving soil water conditions, increasing water content of plant fibres, dissolving nutrients \& making them available to plants. Irrigation also affects temperature conditions by regulating the temperature of surface layer of soil \& ground layer of air; and thus, makes it possible to control the growth \& development of plants and finally the improvement in quality of the harvest. It has been a well-established fact that the irrigated agriculture offers optimum levels of moisture \& sugar content in fruit crops, better oil contents \& seeds in oil crops, better protein contents in rice, wheat \& other grains, and better-quality fibre in cotton/jutes.

Achieving water savings in above cited irrigation water uses, by increases in water use efficiency is emerging as a sensitive factor to meet overall irrigation water demands, by satisfying both current $\&$ future needs of water resources. Irrigated agriculture is increasingly feeling the pressure to both demonstrate and improve upon its performance. India's current irrigation coverage of $48.7 \%$ of total sown area means, two-quarters of the population engaged in farming are 


\title{
International Advanced Research Journal in Science, Engineering and Technology
}

\author{
Vol. 5, Issue 10, October 2018
}

dependent on monsoon rainfall, which often exacerbates agrarian distress even during a short spell partial drought. Out of a total 140.13 million hectares of sown area, India's net irrigated area is 68.38 million hectares while 71.74 million hectares are still remains un-irrigated. To bridge this gap, most recently the government launched the Pradhan Mantri Krishi Sinchayee Yojana (PMKSY) in 2015-16 by coalescing ongoing irrigated related schemes. Under the more crop per drop component of PMKSY, small farmers get paid more than $50 \%$ cost of advanced irrigation systems on their farms. Most recently, in accordance to Haq (2018) the micro-irrigation projects under the PMKSY, marched ahead towards making India drought-proof and producing "more crop per drop". It has well, steadily met targets since its launch. With good impacts of such irrigation-based R\&D intervention, at the national level, coverage of microirrigation networks almost beats the due targets (5.72 lakhs ha against a target of 5.0 lakhs ha in 2015-16; and 8.39 lakhs ha against a target of 8.0 ha in 2016-17).

On an average about one third of the available water (as rainfall, surface or groundwater) always needs to be handled with a greater care for its effectual utilization in growing crops \& other related stuff for meeting demands of food for humans and animals. Many past researchers (Batchelor, 1999; Carter et al. 1999; Pereira et al. 1996; and Howell et al. 1995) have well established facts to attain higher water use productivities from irrigated lands. Irrigation in India includes a network of major and minor canals from Indian rivers, groundwater well based systems, tanks, and other rainwater harvesting projects for agricultural activities. Of these groundwater systems remains largest followed by canal-based irrigation water supplies. In current times, the canal irrigation is attracting vast attention to make a halt on excessive groundwater withdrawal at one end, while safeguarding environmental needs on other. From system point of view, the canal irrigation happens to be the well proved vital form of irrigation in India. Being cheaper, it is of greatest advantage in the river valley regions, with a great role for modernization of irrigation by serving multiple purposes (irrigation, power generation, flood controlling etc). Often any canal irrigation remains of two types, namely: 'inundation canal' or 'perennial canal'. Inundation canals are taken out from the rivers, and they do not have any kind of weir at their head to regulate the flow of water from the river. During rainy season, the river gets flooded and the flood water overflows into these canals. Moreover, 'perennial canals' maintain its flow of water throughout the year even during non-rainy season, and draw their water either from rivers or from reservoir of the river projects with a provision of weirs, sluice gates, and many more hydraulic structures to regulate the water flows and supplies.

Long lasting benefits of above described irrigation-based development can only be achieved through methods that preserve the productivity of water \& land resources even under stress. Hence, the region specific real ground investigations on irrigation system performance are crucial aspects both for researchers as well as field functionaries who so ever deals with irrigation water supplies and also the irrigation stakeholders at far end nodes i.e. the farmers or growers. If we consider the seepage loss from irrigation canals, it is quite established fact that it constitutes a substantial $\%$ of the usable water. Also, the magnitude of conveyance losses during canal irrigation in the alluvial plains of India, happens to be of relatively higher magnitude. Under some Indian conditions by the time the water reaches the farmer's field, it is appraised that the seepage losses attain the values as high as even $45 \%$ of water supplied at the head of the canal (Sharma and Chawla 1975). Seepage from unlined canals in India were reported by them ranging from 0.3 to 7.0 $\mathrm{m}^{3} / \mathrm{s}$ per $100 \mathrm{~m}^{2}$ of wetted surface. Such transit losses are reported more accentuated in alluvial canals. Also, it was established that if the seepage loss could be anyhow prevented, ample additional irrigated area could be created in India. Controlling such transmission losses becomes more vital as it does not only contribute in depleting freshwater resources but also causes side problems like water logging, salinization, and ground-water contamination.

Present study is focused to share some of the preliminary on-ground observations \& results in regards to prevailing magnitudes and ranges of water transmission losses, water use efficiencies, and water use productivities from 3 specified micro cultural command areas under a giant irrigation project, namely Sardar Sarover Narmada Nigam Limited (SSNNL) irrigation project in Gujarat state of India. The project is basically founded in river Narmada, that provides irrigation facilities to about 18.5 lakh ha. of land, covering 3112 villages of 73 talukas in 15 districts of Gujarat. It also has provision for irrigating about 2.64 lakh ha of land in the premeditated desert districts of Barmer and Jallore of Rajasthan and 0.375 lakhs ha land in the tribal hilly tract of Maharashtra by exploiting lift irrigation option. About $75 \%$ of the command area in Gujarat is drought prone, encompassing tribal dominated areas of Gujarat, which lies mostly in Middle Gujarat region. The entire canal command is alienated in 13 Agro-Climatic Sub-regions. In phase-1, the facility to provide irrigation in first 5 zones was completed to cater an area of 4.5 lakh ha of 5 districts viz; Vadodara, Bharuch, Nadiad, Narmada, and Panchmahal districts. Alike to any eminence like irrigation systems (Fig. 1) it comprised vast number of system elements implementing interstate multipurpose project. It effectually manages Narmada river water through a distribution network of about $89931 \mathrm{kms}$, encompassing several branch canals, distributaries, minors and sub-minors. In this giant irrigation project, the water system is supplied from a concrete gravity dam on the river, encircling variety of conveyance \& regulatory systems for storing \& releasing and controlling irrigation water (Table-1). All such canal operating system/structures of this conveyance system are used for ample design flows adopting the concept of "controlled volume" which notably reduces the due response time of the irrigation system. 


\section{International Advanced Research Journal in Science, Engineering and Technology}

Vol. 5, Issue 10, October 2018
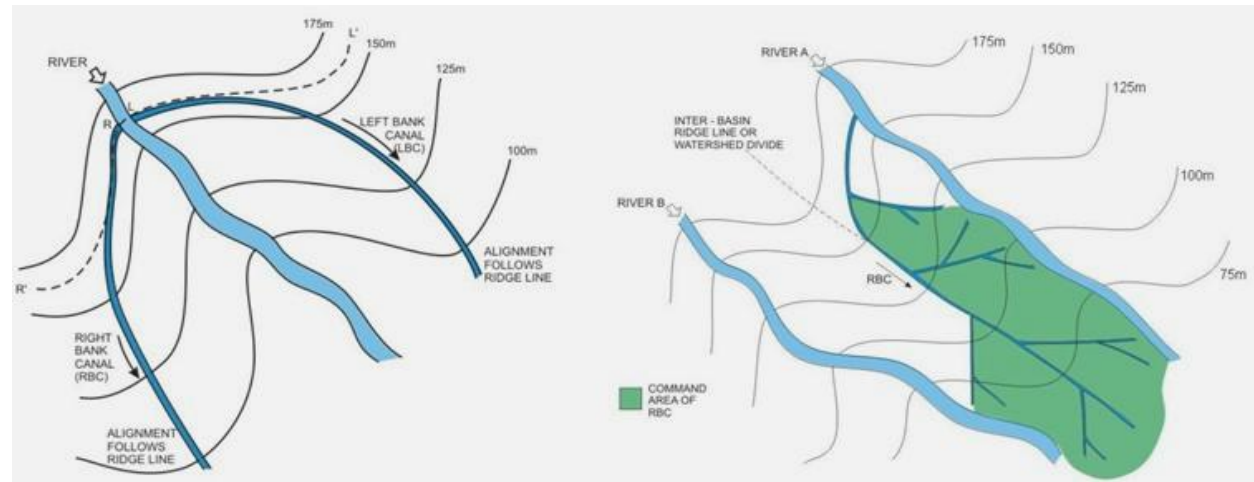

Fig. 1 Physiographic configurations of canal alignments \& command area for a typical canal system

The command area comprises many branch canals along its prime chainage line (Table 1) which caters the irrigation needs in varied level of effectiveness. With a view to understand and evaluate the prevailing performance of these systems at tail ends i.e. near farmer's field, 3 smaller areas were adopted to get some field level insights into realistic status of irrigation water efficiency, conveyance losses and the net flow regimes/ patterns as favoured by researchers like Bhramloo (2007). Our study incorporates three specific micro commands (herein termed as sub minors) where few initial surveys at farmer's field level were conducted and prevailing status of irrigation water utilization as well losses was assessed; which are interpreted and shared herewith.

Table: 1 Major branch canals of Sardar Sarovar project of Narmada main canal (NMC) with chainage values

\begin{tabular}{llllll}
\hline \multicolumn{7}{l}{ Names of Branch Canals with Chainage (KM) } & \\
\hline - & Wadia & $(9.931)$ & $\bullet$ & Daskroi & $(223.67)$ \\
- & Tilakwada & $(17.871)$ & $\bullet$ & Dholka & $(246.29)$ \\
- & Mandwa & $(25.263)$ & $\bullet$ & Sanand & $(258.63)$ \\
- & Bhiloda & $(32.694)$ & $\bullet$ & Saurastra & $(263.20)$ \\
- & Timbi & $(38.523)$ & $\bullet$ & Viramgham & $(267.06)$ \\
- & Sankheda & $(45.109)$ & $\bullet$ & Goriya & $(290.61)$ \\
- & Miyagham & $(62.916)$ & $\bullet$ & Kharghoda & $(292.398)$ \\
- & Gojali & $(70.236)$ & $\bullet$ & Zinzuwada & $(301.041)$ \\
- & Vadodra & $(81.834)$ & $\bullet$ & Bolero & $(326.389)$ \\
- & Dena & $(88.770)$ & $\bullet$ & Rajpura & $(344.772)$ \\
- & Dumad & $(100.01)$ & $\bullet$ & Amarapura & $(354.000)$ \\
- & Sakrda & $(102.95)$ & $\bullet$ & Radhnpur & $(374.486)$ \\
- & Zumkha & $(106.90)$ & $\bullet$ & Kachchh & $(385.081)$ \\
- & Nahra & $(11.65)$ & $\bullet$ & Vejpur & $(405.722)$ \\
- & Desar & $(126.65)$ & $\bullet$ & Madka & $(417.792)$ \\
- & Sansali & $(171.96)$ & $\bullet$ & Malsan & $(423.732)$ \\
- & Memdabad & $(187.07)$ & $\bullet$ & Dhima & $(438.552)$ \\
- & Ghodasar & $(202.37)$ & $\bullet$ & Godasisar & $(453.837)$ \\
- & Vehlal & $(212.55)$ & & & \\
\hline
\end{tabular}

Note : Figures in parenthesis are NMC chainage in Km

\section{MATERIALS AND METHODS}

An easy way to comply with the conference paper formatting requirements is to use this document as a template and simply type your text into it.

A. Brief Description of Study Area: The SSNNL project is originally being attempted in five different phases. The area incorporated in present study remains the extent that falls under $\mathrm{II}^{\mathrm{nd}}$ phase of this giant irrigation project (2010-11 Rabi season). This study was carried out in predetermined limited locations nearing middle Gujarat region at sub-minors namely, Sankheda, Umra (Jambusar), and Kadadara-Vehlal area which had different size of irrigated command having tribal farmers in majority. The main crops of study regions remained maize, paddy, cotton, mung, wheat, jowar, bajra, tur and vegetables. The selected 3 sub-minors had dominated specific crops of maize, castor, and cotton respectively. Irrigation water was principally diverted from SSNNL reservoir to actual irrigated fields via main canal, branch canals, minor canals, and sub-minor canals. In present analysis all the 3 sub-minors adopted, were infect 


\title{
International Advanced Research Journal in Science, Engineering and Technology
}

\author{
Vol. 5, Issue 10, October 2018
}

having concrete lining. Overall, the command area of Sankheda minor was about 625 ha out of which the adopted subminor (SM-2 Block-5) was of 62 ha. The total length of this sub-minor was approximately 1.9 kms ; comprising an average cross section of about $0.38 \mathrm{~m} \times 0.38 \mathrm{~m}$ with a discharge capacity of around 1.0 cusecs at head and 0.6 cusecs at tail. The total numbers of beneficiaries in this area remained about 24, from whom various basic information and ground data were generated. Similarly, the potential irrigated area from Umara minor was found as 447 ha, out of which a micro sub-minor (SM-OL-1 Block-9A6) was earmarked and adopted in this study. It was having similar cross section $(0.38 \mathrm{~m} \mathrm{x} 0.38 \mathrm{~m})$ but encircling an area of to the tune of 42 ha. The length of sub minor was about $5.45 \mathrm{~km}$, delivering a discharge of 1.01 cusecs at head and 0.88 cusecs at tail. The total numbers of beneficiaries located herein were remained 86, whose input was found important to reveal the facts about real field functioning of this sub-minor. The command area under Kadadara-Vehlal minor was about 746 ha, out of which a smaller 56 ha sub-minor (SM-9) was set aside for conducting ground investigations for judging the on-ground functioning of irrigation water supply systems. Approximate length of this particular sub-minor was only $1.3 \mathrm{~km}$, with canal cross-section of $0.30 \mathrm{~m} \mathrm{x} 0.35 \mathrm{~m}$, offering a discharge of 0.85 cusecs at head \& 0.55 cusecs at tail. Total numbers of beneficiaries in this smallest subminor were about 45 in number, who provided ample feedback and benchmark information in line with the core objectives of this study. A physiographical representation of whole command area of SSNNL irrigation project as well as the study area adopted herein is illustrated in Fig. 2

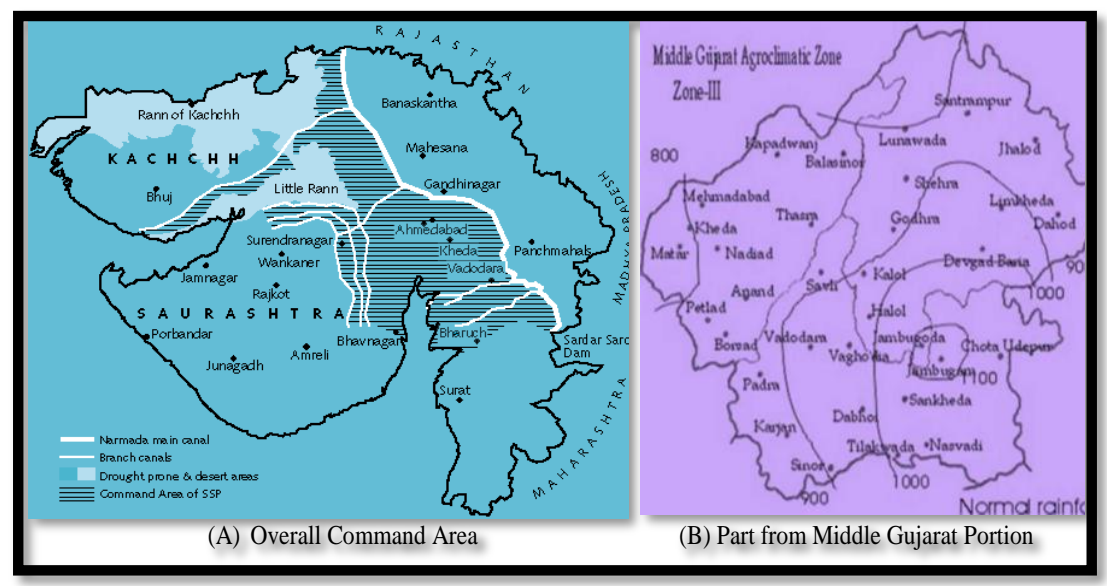

Fig. 2 Map indicating command areas under SSNNL during different phases (Source : SSNNL, 2018)

B. Observations/ Information Collected: The measurements pertaining to discharges, were carried by using suitable discharge measuring systematic devices \& methods like Parshall flumes and velocity-area approach (float method). Other observations were generated by adopting the standard formats, procedures and protocols, retrieving real field information at grass root level and complementary checks via well-organized interviewing \& surveying in participatory mode with farmers and relevant field functionaries of irrigation systems. Field tests were conducted to visualize and record the magnitudes as well as trends of variations in movements of irrigation water fronts (both advanced and recession phases). Relevant computations were carried by using the reliable real field observations from all the 3 sub-minors, which were having 3 specific crops with explicit nature of water use efficiencies and losses.

Table 2 Methodological details for computing infiltration, conveyance loss and WUEs across sub-minors

\begin{tabular}{|c|c|c|}
\hline Entity & Equation & $\mathrm{Eq}$ \\
\hline Soil Infiltration Rate $\left(\mathrm{F}_{\mathrm{c}}\right)$ & $\begin{array}{l}\mathrm{F}_{\mathrm{c}}=\mathrm{k}(\mathrm{T})^{\mathrm{m}} \\
\mathrm{F}_{\mathrm{c}} \text { is steady state infiltration rate in } \mathrm{cm} / \mathrm{hr} \text {, T is elapsed time in hours, } \\
\mathrm{k} \& \mathrm{~m} \text { are location specific parameters derived by conducting on-field } \\
\text { double ring infiltrometer test runs at } 3 \text { sub-minors. }\end{array}$ & (1) \\
\hline $\begin{array}{l}\text { Conveyance Losses(CL) was } \\
\text { considered to consists losses of } \\
\text { irrigation water during operation, } \\
\text { evaporation, and seepage into the } \\
\text { soil from sloping surfaces/canal bed }\end{array}$ & $\begin{array}{l}C L=Q_{i}-Q_{o}-E-D-I \\
\left(C L \text { is meant for a given canal segment, } Q_{i} \text { is inflow to that segment at }\right. \\
\text { head location in litres/sec, } Q_{o} \text { is outflow from that segment at tail end, } \\
\text { E is evaporation losses \& I is added inflow to given segment, and D is } \\
\text { irrigation water diverted from the - all in litres/sec). }\end{array}$ & (2) \\
\hline $\begin{array}{l}\text { WUE was taken as yield of } \\
\text { marketable crop produced per unit } \\
\text { water used in evapotranspiration }\end{array}$ & $\begin{array}{l}\text { WUE }=\mathrm{Y} / \mathrm{ET} \\
\text { (WUE is in } \mathrm{Kg} / \mathrm{ha} / \mathrm{mm} \text { of irrigation water; } \mathrm{Y} \text { is marketable crop yield } \\
\text { in } \mathrm{kg} / \mathrm{ha} \text {; and ET is depth of water applied in the field in } \mathrm{mm} \text { ) }\end{array}$ & (3) \\
\hline
\end{tabular}

The prime indicators namely, water supplied, times in fulfilling advancements and recessions of irrigation water fronts to cover whole irrigated area under given sets of operative conditions (discharges, durations, irrigation water needs, 


\title{
International Advanced Research Journal in Science, Engineering and Technology
}

\author{
Vol. 5, Issue 10, October 2018
}

delivery settings etc), water use efficiencies, conveyance losses, nature $\&$ trends of water front advances \& recessions, infiltration rates etc were detected \& documented at numerous locations at multiple times. These annotations were judiciously utilized to work out standard indices, by adopting well established methods, whose procedural steps remained as follows,

Soil Infiltration: The soil infiltration rate plays a decisive role in overall success \& effectiveness of any irrigation system. Researchers have found It is found to have vast variabilities across time and space under different soilvegetation cover complexes (Gaur, 2003; Gaur and Singh, 1995). Same was studied by adopting double-ring infiltrometers, and conducting real ground test runs at appropriate representative locations inside the study sub-minors. The observed variations in infiltration rates were suitably compared and fitted into a generalized infiltration equation (Eq-1, Table2) to generate the pairs of values for constants of this particular equations, which gave a realistic estimation of the steady state infiltration rates whatever prevailing in 3 sub-minor areas as adopted in present study.

Conveyance Losses : Water conveyance loss consists mainly of operation losses, evaporation, and seepage into the soil from the sloping surfaces and bed of the canal (Michael, 1978; Koradiya and Khasiya, 2014; Singh et al. 2013). From practical points of view the most important of these is seepage, while the evaporation loss (specifically in small sized micro commands) is often ignored. Some of the researchers worked on SSNNL evaluation tasks have the opinion that seepage loss in the irrigation canals on the right and left banks at initial stages at certain critical locations was highly vulnerable. The problems resulting from water conveyance loss due to seepage in canals could be divided into 2 groups. The first is prodigality of water, which is obtained at a high cost and with difficulty from various sources. The second is the problem of drainage, salinity, and alkalinity, which result from a rising water table. Researchers (Wachyan and Rushton, 1987; Swamee et al. 2999; Akkuzu et al. 2012; Karad et al. 2013) have amply researched the importance and quantified values of various kinds of losses during water transmission via canals and overall canal based irrigations systems; offering plethora of empirical as well as physical based prediction techniques to reflect seepage or alike losses. A popular approach of using an inflow-outflow method has always been a popular approach to look upon such irrigation water losses. Eq-2 in Table 2 was suitably utilized to derive region specific values of water conveyance loss, which could be reflected in variety of ways viz. (i) conveyance loss per unit of canal length $(\mathrm{L} / \mathrm{S} / \mathrm{Km}$ or L/S/100m), (ii) conveyance loss as a percentage of inflow (per Km or per $100 \mathrm{~m}$ ), and (iii) conveyance loss per unit time $\&$ area $\left(\mathrm{L} / \mathrm{S} / \mathrm{m}^{2}\right)$. Flows at the beginning and at the end of canal segments of the main trapezoidal sub-minors were computed by adopting the velocity-flow area measurement technique. Evaporation losses (E) were neglected in present study for all the 3 sub minors as they were almost insignificant in their magnitudes. Since there was there was no flow into the canal segment from outside (I), or no any irrigation volume was diverted from the canal segment (D), both these values were considered nil.

Water Use Efficiency : Plant water use efficiency (WUE) is fetching extreme importance in semiarid areas, where crop production relies on the use of large volumes of water. Improving WUE has been always advocated as one of the best approaches for securing environmental sustainability of food production in these areas. WUE has vast variabilities across space-time domain, and has complex relationship with managerial aspects of local environment and irrigation water systems. Borrell (1997) postulated that if the crop yields (Y) are proportional to evapotranspiration (ET), water use efficiency has to be persistent but it never found as constant. It altogether vindicates the fact that the Y and ET are influenced independently by crop management and environment. Yield was found more influenced by crop management practices, while ET remains solely dependent on climate and soil moisture. Fertilization and other cultural practices for high yield usually found to increase the absolute water use. It altogether established the fact that crop production can be significantly augmented by judicious \& effective irrigation water applications even sidelining the adverse influences of increased ET. Under optimum irrigation water supply scenarios, ET does not remain dependent on kind of plant canopy provided the soil is adequately covered with crop. Irrigation researchers (Grimble, 1995; Dinar, 1993) have well realized that increasing the amount of plant canopy has little or no effect on ET, once an optimum \& effectual irrigation schedule is applied to promote plant growth with efficient use of sunlight in photosynthesis without causing a corresponding increase in ET. It altogether enhances the field based WUE, in accordance to nature of the plant, climatic condition, soil moisture content, fertilizers, plant population, irrigation water depths, crop yields, extent of uniform crop. We have worked out appropriate values of WUEs. (Eq-3 Table 2) for 3 specific sub-minors and compared them for their relative inconsistencies even across micro irrigation commands with cropping systems.

Advancing \& Recession of Irrigation Water Fronts: Efforts were made to generate some information on pattern and relative variability on advance and recession of water front as experienced at tail ends. As the irrigation stream is introduced into a border strip, an ever-decreasing portion of the total volume applied flows above the ground, while the remainder infiltrates into the soil and comprises the soil moister storage. The major variables which were found to influence the rate of the water front were: (1) Size of the irrigation stream, (2) Infiltration characteristics of the soil, (3) Roughness of the land surface, (4) Vegetative retardance, (5) Land slope, (6) Elapsed time. 


\title{
International Advanced Research Journal in Science, Engineering and Technology
}

\author{
Vol. 5, Issue 10, October 2018
}

Other Associated Information : Details in regards to prevailing soils ands and agricultural systems of study sub-minors were worked out by generating arrays of key information. The soil samples were collected from all three sub-minors from randomly decided locations covering two dissimilar depths of soil (i.e. 0-15 cm and $15-30 \mathrm{~cm}$ ). In all about 12 soil samples were collected and analysed in lab for soil status in regards to soil fertility status \& physico-chemical properties. Supplemental information to create benchmark knowledge on socio-economic profile of the farmers and villagers was too assessed by performing a interaction surveying with selected farmers. It was established that canal irrigation has totally transformed and uplifted the crop yields and income scenarios in the sub-minors. The agricultural system herein was totally rain fed before introduction of this canal irrigation system.

\section{RESULTS AND DISCUSSION}

After surveying \& studying, plethora of observations were recorded across study sub-minors; which incorporated entities like supplied irrigation (rates \& volumes), infiltration rates, advancing \& recession rates of irrigation water fronts, detailed physiographic configurations of micro commands, cropping system, crop yields, and canal physics to regulate conveyance losses. The brief extract of these values and their inter comparison is portrayed in below given segments with categorical relative comparisons for Sankheda, Umara and Kadadara sub minors of SSNNL irrigation scheme. The variabilities as well as interrelationships across them is illustrated in terms of appropriate figures and tables, which is self-explanatory to realise the magnitude and trends of variabilities.

A. Salient Results from Sankheda Sub Minor

This particular sub-minor was having Maize as a predominant crop. Appropriate sets of observations were collected and utilized to compute various parameters and entities as elaborated in methodological elaboration in preceding segment of this writeup. Some of the basic observed values in this sub-minor remained as follows which were subsequently utilized for working out infiltration, rates of advancing/recessions, CL, WUE and other derivatives,

- Throat width \& Discharge rate of Parshall flume $(7.5 \mathrm{~cm} ; 4.3$ litres/ sec)

- Field dimension \& area $\left(60 \mathrm{~m} \times 71 \mathrm{~m} ; 4260 \mathrm{~m}^{2}\right)$

- $\quad$ Length \& Width of the furrow (60 m x $0.6 \mathrm{~m})$

- Regional values of constants ' $\mathrm{k}$ ' \& ' $\mathrm{m}$ ' in infiltration equation quoted as Eq-1 in Table 2 (0.571 \& 0.628)

- Water delivered to the field $\left(15.48 \mathrm{~m}^{3} / \mathrm{hr}\right)$

- $\quad$ Time required to irrigate 1 ha land $(32.87 \mathrm{hrs})$

- Water required to irrigate 1 ha land $\left(508.83 \mathrm{~m}^{3}\right)$

- $\quad$ Average irrigation water depth in 1 ha land $(0.050883 \mathrm{~m}$ i.e. $50.88 \mathrm{~mm})$

- Culturable command area \& canal bed gradient of sub-minor (62 ha; 1:1000)

- Maize crop yield \& total beneficiaries in micro command $(2548 \mathrm{Kg} / \mathrm{ha} \& 24)$

- No of irrigation, irrigation water depth per irrigation, total applied irrigation (5 nos, $50.88 \mathrm{~mm}, 254.4 \mathrm{~mm}$ )

- WUE $(10.017 \mathrm{~kg} / \mathrm{ha} / \mathrm{mm}$ of irrigation water $)$

- Length, cross section, effective cross sectional area of canal segment $\left(1.925 \mathrm{~km} ; 0.38 \mathrm{~m} \times 0.30 \mathrm{~m} ; 0.144 \mathrm{~m}^{2}\right)$

- Discharge rates at head $\&$ tail ends $(1.0 \& 0.69$ cusecs $)$

- Total conveyance loss from head to tail \& Conveyance efficiency $(0.31$ cusec \& $69 \%)$

B. Salient Results from Umara Sub Minor

This particular sub-minor was having Maize as a predominant crop. Appropriate sets of observations were collected and utilized to compute various parameters and entities as elaborated in methodological elaboration in preceding segment of this writeup. Some of the basic observed values in this sub-minors remained as follows which were subsequently utilized for working out infiltration, rates of advancing/recessions, CL, WUE and other derivatives,

- $\quad$ Throat width \& Discharge rate of Parshall flume $(7.5 \mathrm{~cm} ; 5.0$ litres/ sec)

- $\quad$ Field dimension \& area $\left(112 \mathrm{~m}\right.$ x $\left.55 \mathrm{~m} ; 6160 \mathrm{~m}^{2}\right)$

- $\quad$ Length \& Width of the furrow (55 m x $1.8 \mathrm{~m})$

- Regional values of constants ' $\mathrm{k}$ ' \& ' $\mathrm{m}$ ' in infiltration equation quoted as Eq-1 in Table 2 (0.591 \& 0.661$)$

- Water delivered to the field $\left(15.48 \mathrm{~m}^{3} / \mathrm{hr}\right)$

- $\quad$ Time required to irrigate 1 ha land $(27.59 \mathrm{hrs})$

- Water required to irrigate 1 ha land $\left(496.62 \mathrm{~m}^{3}\right)$

- Average irrigation water depth in 1 ha land (0.04966 m i.e. $49.66 \mathrm{~mm})$

- Culturable command area \& canal bed gradient of sub-minor (62 ha; 1:1000)

- Maize crop yield \& total beneficiaries in micro command $(2023 \mathrm{Kg} / \mathrm{ha} \& 86)$

- No of irrigation, irrigation water depth per irrigation, total applied irrigation (5 nos, $49.66 \mathrm{~mm}, 248.3 \mathrm{~mm}$ )

- WUE $(8.146 \mathrm{~kg} / \mathrm{ha} / \mathrm{mm}$ of irrigation water)

- Length, cross section, effective cross-sectional area of canal segment $\left(1.1 \mathrm{~km} ; 0.38 \mathrm{~m} \times 0.30 \mathrm{~m} ; 0.144 \mathrm{~m}^{2}\right)$ 


\section{International Advanced Research Journal in Science, Engineering and Technology}

Vol. 5, Issue 10, October 2018

- Discharge rates at head \& tail ends ( $1.01 \& 0.58$ cusecs)

- Total conveyance loss from head to tail \& Conveyance efficiency ( 0.43 cusec \& $57.4 \%)$

C. Salient Results from Kadaadra-Vehlal Sub Minor

This particular sub-minor was having Maize as a predominant crop. Appropriate sets of observations were collected and utilized to compute various parameters and entities as elaborated in methodological elaboration in preceding segment of this writeup. Some of the basic observed values in this sub-minors remained as follows which were subsequently utilized for working out infiltration, rates of advancing/recessions, CL, WUE and other derivatives,

- Throat width \& Discharge rate of Parshall flume $(7.5 \mathrm{~cm} ; 5.0$ litres/ sec)

- $\quad$ Field dimension \& area $\left(31 \mathrm{~m}\right.$ x $\left.56 \mathrm{~m} ; 1736 \mathrm{~m}^{2}\right)$

- $\quad$ Length \& Width of the furrow (30 m x $1.6 \mathrm{~m}$ )

- Regional values of constants ' $k$ ' \& ' $m$ ' in infiltration equation quoted as Eq-1 in Table 2 (0.591 \& 0.661$)$

- Water delivered to the field $\left(18 \mathrm{~m}^{3} / \mathrm{hr}\right)$

- $\quad$ Time required to irrigate 1 ha land $(28.8 \mathrm{hrs})$

- Water required to irrigate 1 ha land $\left(518.43 \mathrm{~m}^{3}\right)$

- Average irrigation water depth in 1 ha land $(0.05184 \mathrm{~m}$ i.e. $51.84 \mathrm{~mm})$

- Culturable command area \& canal bed gradient of sub-minor (56 ha; $1: 1000)$

- Maize crop yield \& total beneficiaries in micro command $(2490 \mathrm{Kg} / \mathrm{ha} \& 24)$

- No of irrigation, irrigation water depth per irrigation, total applied irrigation (11 nos, $51.84 \mathrm{~mm}, 570.2 \mathrm{~mm})$

- WUE $(4.366 \mathrm{~kg} / \mathrm{ha} / \mathrm{mm}$ of irrigation water)

- $\quad$ Length, cross section, effective cross sectional area of canal segment $\left(1.3 \mathrm{~km} ; 0.38 \mathrm{~m} \times 0.34 \mathrm{~m} ; 0.186 \mathrm{~m}^{2}\right)$

- $\quad$ Discharge rates at head $\&$ tail ends $(1.0 \& 0.69$ cusecs $)$

- Total conveyance loss from head to tail \& Conveyance efficiency $(0.31$ cusec \& $69 \%)$

D. Discussion on Relative Variations of Results across 3 Sub-Minors

Above described summarized end results, as drawn for 3 specific sub-minors; well reflects the eventual spectrum of operational behaviour of irrigation systems and corresponding cropping behaviour to response in terms of various indicators (water delivered, WUE, conveyance losses/efficiencies, soil infiltration etc). A composite \& condensed comparison in this regard is presented in Fig. 3, where the observed ranges of certain key indicators are graphically compared for 3 specific sub-minors. Water delivery rate was detected higher in Kodadara -Vehla sub minor $\left(18 \mathrm{~m}^{3} / \mathrm{hr}\right)$ which was about $15 \%$ higher as compare to other two sub-minors. However, the ultimate WUE attained in this subminor remained lowest $(4.37 \mathrm{Kg} / \mathrm{ha} / \mathrm{mm})$ which use to be about $56 \%$ \& $46 \%$ lower than Sankheda \& Umra sub minor respectively. The average irrigation water depths almost oscillated between 50 to $52 \mathrm{~mm}$ per irrigation, however the number of irrigations in cotton crop in Kodadra-Vehla sub-minor

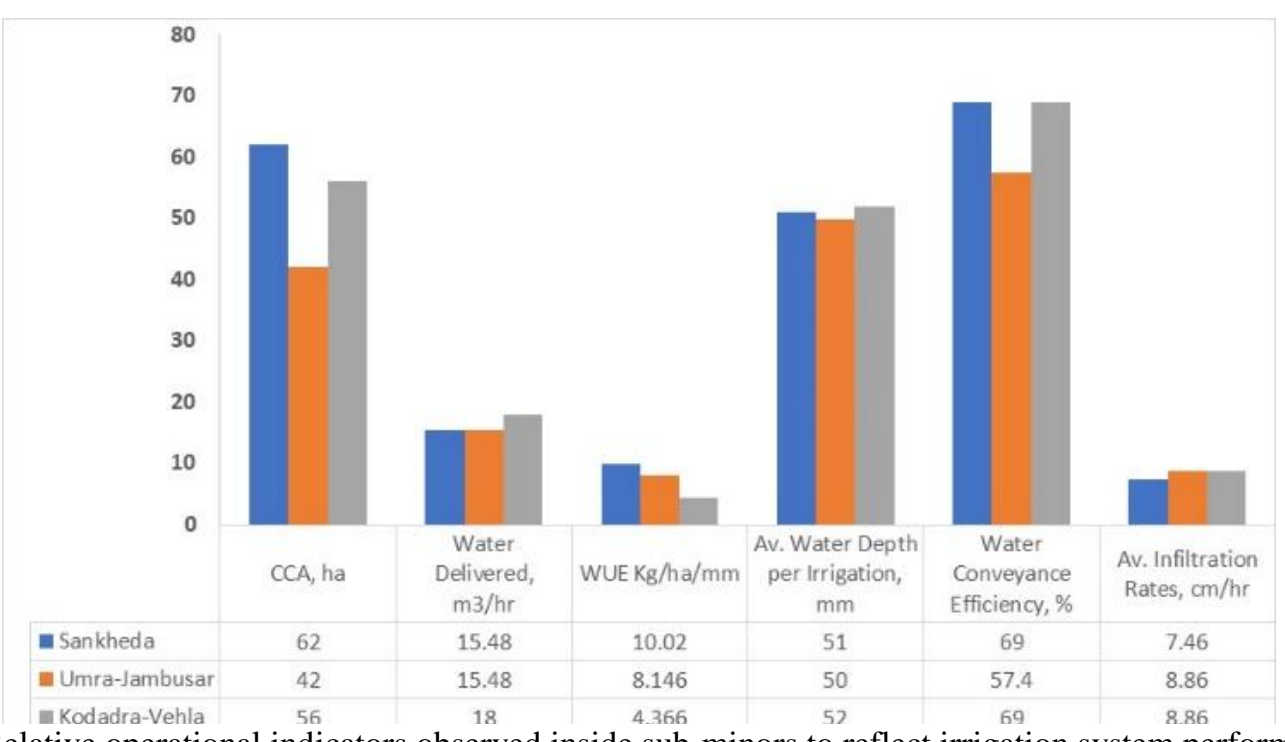

Fig. 3 Relative operational indicators observed inside sub-minors to reflect irrigation system performance

Though the culturable command areas of study sub-minors had significant variability in their extent (30 to 35 variabilities), ultimate influences on irrigation system's act remained of varied nature as illustrated in Fig. 3. Results revealed that the actual field-based results/observations from sub minors revealed that with prevailing sets of operational configurations e fact that, observed time as required for irrigating the area of $4260 \mathrm{~m}^{2}$ comes out to be about 


\title{
International Advanced Research Journal in Science, Engineering and Technology
}

\author{
Vol. 5, Issue 10, October 2018
}

14 hours. Thus, for whole Sankheda sub minor (Chuck no. 1 having gross 62 ha as culturable command area), with the condition/presumption that this sub-minor is flowing at FSL, 21 days remains the indirect rough approximation accomplish irrigation of full area under Chuck no. 1. It altogether reflected ample scope of improvement of WUE inside the micro command area for achieving even better water productivity of maize crop. In case of Umra (JambusarChuck no. 1), the similar time needed for irrigating filed area $\left(6160 \mathrm{~m}^{2}\right)$ was found to be about 17 hours, which gave an indirect estimate of time required to irrigate whole command area (42 ha) of this sub-minor as high as 48.5 days, even if full supply level is there. In case of Kadadara -Vahelal sub-minor the time required to irrigate field $\left(1736 \mathrm{~m}^{2}\right)$ was detected as 5 hours, with which the whole command area ( 56 ha) could be covered in 17 days canal running time.

Water conveyance losses were found highest in Umra sub-minor, while in other two sub-minors these losses were about $25 \%$ less. Similarly, the WUE was found to be highest in Sankheda \& Kodadra-Vehla Subminors. The leading factor to govern the WUE was the type of crop and number of irrigation water applications it demanded to sustain crop growth \& yield. Table 3 portrayed a crop based comparison of WUE, across 3 different sub-minors as adopted in this study; where crop demanding behaviour of cotton was found irrational in contrast to other two.

Table: 3 Water needs, yields \& WUEs for 3 different crops at sub-minor scale

\begin{tabular}{|l|l|l|l|l|l|l|}
\hline Sub-Minor & Crop & $\begin{array}{l}\text { No of irrigation } \\
\text { Required }\end{array}$ & $\begin{array}{l}\text { Water } \\
\text { required/ha }\left(\mathrm{m}^{3}\right)\end{array}$ & $\begin{array}{l}\text { Av. Water } \\
\text { depth }(\mathrm{mm})\end{array}$ & $\begin{array}{l}\text { Yield } \\
(\mathrm{kg} / \mathrm{ha})\end{array}$ & $\begin{array}{l}\text { WUE }(\mathrm{kg} / \mathrm{ha} / \mathrm{mm} \\
\text { of water })\end{array}$ \\
\hline Sankheda & Maize & 5 & 508.83 & 50.88 & 2548 & 10.02 \\
\hline Umara & Caster & 5 & 496.62 & 49.62 & 2023 & 8.146 \\
\hline Kadara-Vehlal & Cotton & 11 & 518.43 & 51.84 & 2490 & 4.366 \\
\hline
\end{tabular}

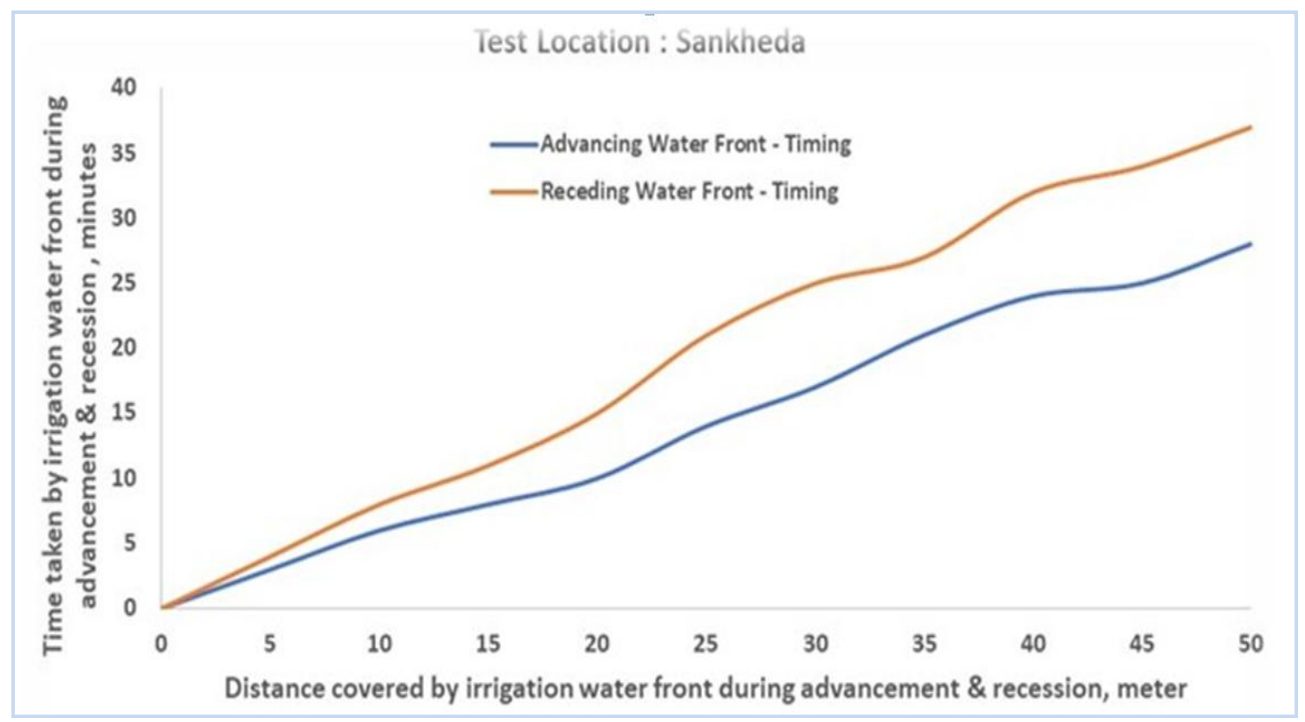

(A) Sankheda Sub-minor (62 ha, Maize as Major Crop)

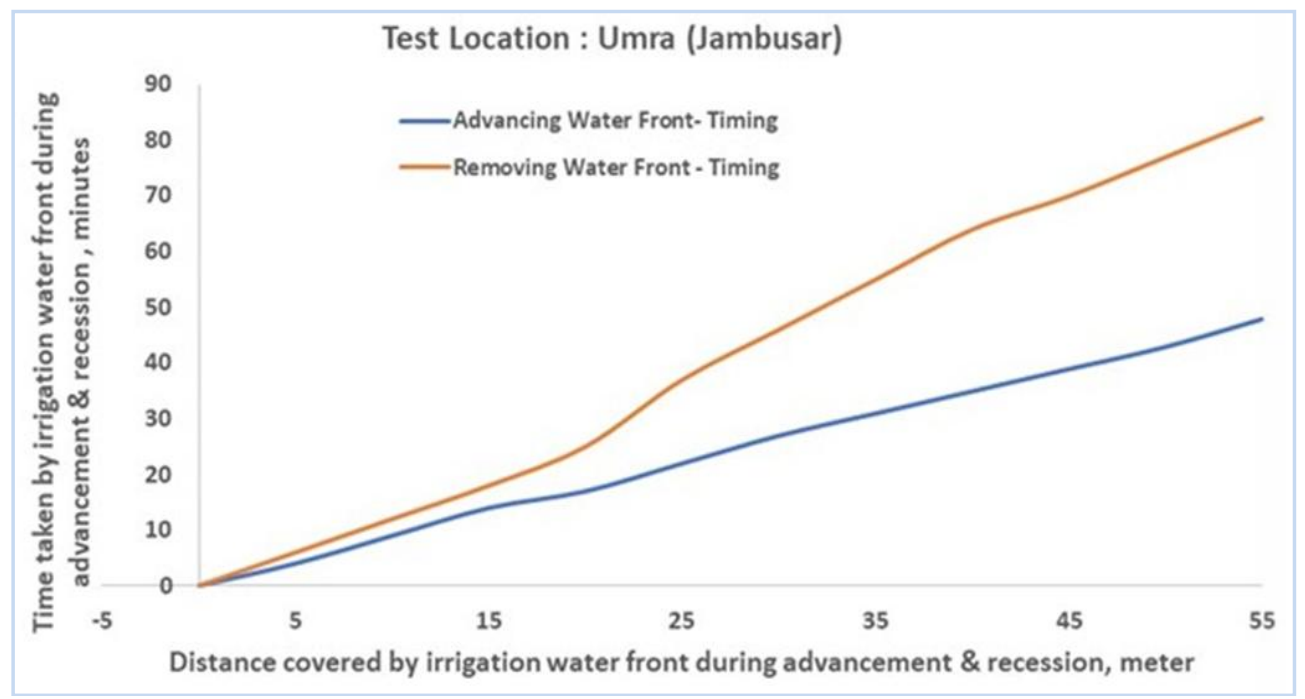

(B) Umra sub-minor (42 ha, Castor as Major Crop) 


\title{
International Advanced Research Journal in Science, Engineering and Technology
}

\author{
Vol. 5, Issue 10, October 2018
}

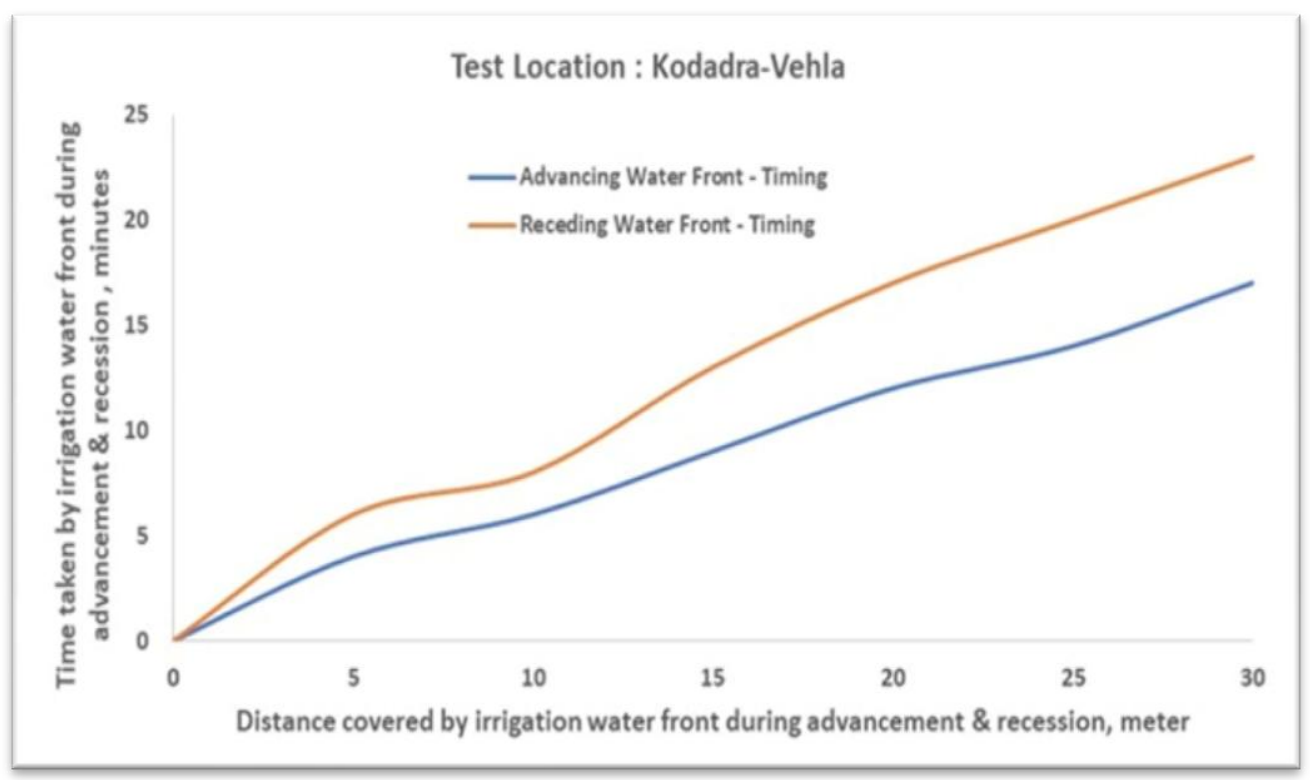

(C) Kodadra - vehla Sub- Minor (56 ha, Cotton as Major Crop)

Fig 4. Fig Variability of Irrigation Water Fronts Movements during Advancing and Recession Phases

Another foremost leading factors to produce such results looks to be the specified patterns of movements of irrigation water fronts (both during advancements as well as recession phases). Detailed results in this regard were arrived to reveal that rates of advancements and recessions were having sizeable differences along the space and time grids. On an average the recession rates were relatively lower as compare to advancing rates, which could be considered a favourable point for offering better opportunities for soil infiltration and thus the soil moisture built up to provide productivity strength to crop root zones. Rates of advancement \& recession of irrigation water front were detected highest in Sankheda sub-minor; which were lowest in Umra sub-minor by an average magnitude of about $50 \%$. A relative comparison of six different sets of curves for all sub-minors is illustrated in Fig. 4; which is understandable to reflect prevailing variations inside the study area.

\section{CONCLUSIONS}

The limited availability of water \& land for irrigated agriculture necessitate effectual operation of irrigation \& cropping systems. Careful manoeuvre and scheduling of irrigation could drastically improve the water use efficiencies (WUE) both at field and command area level. The salient findings from present filed based observations have clearly established the predominant actors with their magnitude as we'll as variability patterns to influence crop water productivities in three specified sub-minors under SSNNL Beside WUEs the quantified variability in water conveyance losses at irrigation field levels were also compared which gave a significant variabilities, which never remained only governed by mere command area, but greatly by other operational configurations inside the commands. Sankheda subminor having highest extent in terms of culturable command area (CCA), but it had exhibited highest rates (velocities) of irrigation water front movements during advancements as well as recessions during active furrow irrigation. Here the conveyance losses too were found sizeably higher as compare to other 2 sub-minors whose CCA was relatively lower. Conveyance losses were found highest in Umra sub-minor irrespective of the fact that it is not a biggest command and the velocities of water front moves were too less (about $50 \%$ of highest that were observed in Sankheda, having largest CCA).

Results altogether have offered important food for thought where following facts are well established for study region,

- Increased irrigation water does not always offer a positive effect to achieve optimum water productivities.

- Regional parametrization towards irrigation scheduling, water conservative strategies,

- Initial reconnaissance \& active participation with irrigation water users at farmer's field scale could be the best strategy before scheduling and operating irrigation water deliveries from sub-minors/irrigation channels.

- On ground information on prevailing cropping systems, crop water demands and its variations in accordance to local climate \& site conditions, physical characteristics of various elements of canal system, status \& potential 


\title{
International Advanced Research Journal in Science, Engineering and Technology
}

\author{
Vol. 5, Issue 10, October 2018
}

of critical maintenances, leakage preventions, timings of deliveries \& drawing of irrigation water supplies, and other factors had immense influences on overall levels of water application efficiencies/transmission losses.

- Exploring and accommodating crop based optimum options (type of crop, variety, planting configurations etc) will certainly deliver many positive benefits towards savings in irrigation water magnitudes as well as energy needs.

- Involving, educating and training farmers and water managers in regards to proper operability of irrigation systems for adequate fine tuning in relation to optimized crop water requirements; could be an important necessity to decide overall operational success of any irrigation command area.

- Low cost and environmentally friendly lining of canals at its far downstream ends (i.e. sub-minors, filed channels etc) are another important aspect which have ample prospects to bridge relevant gaps in study area

- Accurate estimations on real ground irrigation flow rates, soil water losses, and dynamics of irrigation water fronts during advancement and recession played a decisive role in establishing the levels of water savings, water productivities and time/energy savings during on-farm irrigations rom specified sub-minors.

- Proper accounting for irrigation water is gaining a high attention, to judge and establish region specific paradox of irrigation efficiency along with dynamic behaviour of irrigation water inflows \& outflows

- Water Use Efficiency in selected sites of sub-minor was found to be highly variable \& uncertain. Its representative field-based values were worked out to be as $10.02 \mathrm{~kg} / \mathrm{ha} / \mathrm{mm}$ of irrigation water for maize crop, $8.146 \mathrm{~kg} / \mathrm{ha} / \mathrm{mm}$ for caster crop and $4.366 \mathrm{~kg} / \mathrm{ha} / \mathrm{mm}$ of irrigation water for the cotton crop. Steady stead Infiltration rate were found to be as $7.46,8.86,8.86 \mathrm{~cm} / \mathrm{hr}$ in selected sites. Sankheda sub minor area showed a less infiltration rate in contrast to other areas under study. The overall spectrum of WUE as well as conveyance losses, over the study region revealed a food for thought for releasing more serious efforts towards reduction of losses with appropriate scheduling of cropping \& irrigation activities in the command. This could be the only reason for the lots of variation as observed towards prevailing cropping pattern before and after SSNNL project executions.

- The engineering concept of efficiency at different levels of a canal system is important for planning, designing and even operating a canal irrigation system. However, efficiency alone is not an adequate indicator to define the performance of an irrigation system. Indicators of water productivity expressed in terms of production or value of production per unit of water are very important in increasingly water-scarce situation. A canal irrigation system may have high conveyance efficiency with a minimum of seepage and operational losses.

\section{ACKNOWLEDGMENT}

Authors feels deep gratitude while acknowledging the important support \& help from authorities of SSNNL Gandhinagar Gujarat and also the Anand Agril University Anand, Gujarat; for their ample support and inputs in terms of data \& facilities. The participatory inputs from field functionaries \& farmers on study region is highly acknowledged.

\section{REFERENCES}

[1]. Akkuzu E. 2012. Usefulness of Empirical Equations in Assessing Canal Losses through Seepage in Concrete-Lined Canal. Journal of Irrigation Drainage Engineering, ASCE, Vol. 138 (5): 255-260.

[2]. Borrell, A., Garside, A., and Fukai, S. 1997. Improving efficiency of water use for irrigated rice in a semi- arid tropical environment. Field Crops Resources, Vol. 52 : 231-248.

[3]. Batchelor, C. 1999. Improving water use efficiency as part of integrated catchment management. Agril Water Management, Vol.40(2): 249-263.

[4]. Carter, R., Kay, M., and Weatherhea,d K. 1999. Water losses on smallholder irrigation schemes. Agril Water Management, Vol. 40 :115-124.

[5]. Dinar, A. 1993. Economic factors and opportunities as determinants of water use efficiency in agriculture. Irrigation Science, Vol. 14(2): 47-52.

[6]. Gaur, M. L. and Panjab Singh. 1995. Application of Watershed concepts for developing degraded lands of Bundelkhand region. In : Agro Forestry Systems for Degraded Lands of Asia and the Pacific Region (Eds : Panjab Singh, P. S. Pathak and M. M. Roy), Pub : Oxford \& IBH, New Delhi Vol. 2 : 938-946.

[7]. Gaur, M. L. 2003. Characterizing surface infiltration variability in a small natural forest watershed, Indian Forester, Vol. 129(3): 341-348.

[8]. Grimble, R. J. 1999. Economic instruments for improving water use efficiency: Theory \& practice, Agril Water Management, Vol. 40(1):77-82.

[9]. Haq Zia. 2018. Five State's account for 78\% of progress in micro-irrigation. In : Hindustan Times. E-paper. Tuesday Nov. 6, 2018. Available at https://www.hindustantimes.com/india-news/5-states-account-for-78-of-progress-in-micro-irrigation/story.

[10]. Howell, T. A., Yazar, A., Schneider, A. D., Dusek, D. A., and Copeland, K. S. 1995. Yield and water use efficiency of corn in response to LEPA irrigation. Trans of ASAE, Vol. $38: 1737-1747$.

[11]. Karad, M. M., Panke, R. A., and Hangargekar, P. A. 2013. Seepage Losses through Canals \& Minors, IJRET, Vol. 2 (11) : $1125-1134$.

[12]. Koradiya, K. A. and Khasiya, R. B. 2014.Estimate seepage losses in irrigational canal systems. Indian Jr of Applied Research, Vol.4(5):252-255

[13]. Michael, A. M. 1978. Irrigation: Theory and Practice. Pub: Vikas Publishing House, New Delhi, pp 801.

[14]. Pereira, L. S., Gilley, J. R., and Jensen, M. E. 1996. Research agenda on sustainability of irrigated agriculture. Journal of Irrigation Drainage Engineering, ASCE, Vol. 122: 172-177.

[15]. Sardar Sarovar Narmada Nigam Limited Website: http://www.sardarsarovardam.org/ Assessed on 08-11-2018.

[16]. Sharma, H. D., and Chawla, A. S. 1975. Manual of canal lining, Technical Report 14, Central Board of Irrigation \& Power, New Delhi.

[17]. Singh, S.K.; Lal, Chhedi; Shahi, N. C. and Chand, Khan. 2013. Estimation of canal seepage under shallow water table conditions. Journal of Academic and Industrial Research, Vol.1(9): 571-576. 


\title{
International Advanced Research Journal in Science, Engineering and Technology
}

\author{
Vol. 5, Issue 10, October 2018
}

[18]. Swamee, P. K., Mishra, G. C., and Chahar, B. R. 2000. Design of Minimum Seepage Loss Canal Sections, Journal of Irrigation Drainage Engineering, ASCE, Vol. 126 (1) : 28-32.

[19]. Wachyan, E., and Rushton, K. R. 1987. Water losses from irrigation canals, Journal of Hydrology, Amsterdam, Vol. 92 (3,4): 275-288.

\section{BIOGRAPHY}

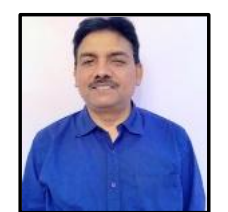

The lead author has more than 34 years multifarious experience in research, education and transfer of technology aspects of natural resources management, soil \& water conservation engineering, watershed planning and management, irrigation and drainage engineering, command area development and management and many other portfolios of agricultural engineering. He obtained his $\mathrm{PhD}$ in the field of Hydrology from Indian Institute of Technology Roorkee and served for about 24 years holding various scientific positions at several National Research Institutions under Indian Council of Agricultural Research, New Delhi. Afterward he had been in agricultural education stream for last 10 years, holding positions of Professor, HOD, Principal, and also the Faculty Dean of Agricultural Engineering under his present organization i.e. Anand Agricultural University. He has more than 50 prime publications in international \& national journals and books with equal number of other publications in diverse fields of watershed, hydrology, grasslands, forest lands, rainfall runoff modeling, GIS\&RS, rainwater harvesting, soil erosion \& sedimentation, wasteland development and climate change/agrometeorological aspects. He has more than 6 national appreciations (medals, awards, fellowships) and several other professional recognitions in his name. Second author, too has > 30 years experience in agricultural education and R\&D in his present organization dealing several teaching and research tasks in soil and water conservation engineering, irrigation and drainage engineering, micro irrigation, and many other related interventions. Third author use to be a past student at college of Agril. Engg. \& Technology Godhra, and presently working as manger in a finance organization for agricultural credits and other relevant issues. 